American Journal of Applied Sciences 3 (11): 2079-2085, 2006

ISSN 1546-9239

(c) 2006 Science Publications

\title{
Bounds Testing Approach to Cointegration: An Examination of Foreign Direct Investment Trade and Growth Relationships
}

\author{
${ }^{1}$ Oteng-Abayie Eric Fosu and ${ }^{2}$ Frimpong Joseph Magnus \\ ${ }^{1}$ School of Business, Garden City University College, P.O. Box KS 12775, Kumasi, Ghana \\ ${ }^{2}$ KNUST School of Business, Kwame Nkrumah University of Science and Technology, Kumasi, Ghana
}

\begin{abstract}
This study examines the long-run impact of foreign direct investment and trade on economic growth in Ghana. Using an augmented aggregate production function (APF) growth model, we apply the bounds testing (ARDL) approach to cointegration which is more appropriate for estimation in small sample studies. The data span for the study is from 1970 to 2002. We found cointegration relations between growth and its determinants in the APF model. The results indicated the impact of FDI on growth to be negative which is consistent with other past studies. Trade however was found to have significant positive impact on growth.
\end{abstract}

Key words: Ghana, FDI, ARDL cointegration, unit roots, equilibrium-correction, trade

\section{INTRODUCTION}

According $^{[1]}$, for a developing country such as Ghana, trade may bring about the upgrading of skills through the importation or adoption of superior production technology and innovation. Exporters learn or adopt better and highly developed production technology and innovation, either through intensive international markets competition or act as subcontractors to foreign business concerns. Producers of import-substitutes in an open economy have to face competition from foreign counterparts. Since their products, within the context of a developing country, are usually capital-intensive, they need to adopt better or more capital-intensive production facilities to survive $^{[2]} .{ }^{[3]}$ has argued that trade openness exerts a positive and significant impact on economic growth due to the accelerated accumulation of physical capital, sustained technological transfer and improvement in macroeconomic policies. Inward FDI (foreign capital inflow) is an important vehicle for augmenting the supply of funds for domestic investment thus promoting capital formation in the host country. Inward FDI can stimulate local investment by increasing domestic investment through links in the production chain when foreign firms buy locally made inputs or when foreign firms supply or source intermediate inputs to local firms. Furthermore, inward FDI can increase the host country's export capacity causing the developing country to increase its foreign exchange earning. FDI is also associated with new job opportunities and enhancement of technology transfer and boosts overall economic growth in host countries.

Trade and FDI inflows have been widely recognised as very important factors in the economic growth process. Past empirical studies, both cross country and country specific, on trade and FDI interaction on growth ${ }^{[4-8]}$, FDI-growth nexus and tradegrowth nexus ${ }^{[9]}$ and $^{[10]}$ have mostly concluded that both FDI inflows and trade promote economic growth. Nevertheless, there are clear indications that the growth enhancing effects from FDI inflows and Trade vary from country to country. For some countries FDI and Trade can even negatively affect the growth process $^{[4,5,9,11,12]}$. According to Bhagwati's well known proposition called Bhagwati's hypothesis, "with due adjustments for differences among countries for their economic size, political attitudes towards FDI and stability, both the magnitude of FDI flows and their efficacy in promoting economic growth will be greater over the long run in countries pursuing the export promotion (EP) strategy than in countries pursuing the import substitution (IS) strategy" ${ }^{\text {"[13,14] }}$. Thus, the growth enhancing effect of FDI and Trade interaction is not automatic but depends on various country specific factors such as the trade openness. Similar conclusion is made by ${ }^{[15]}$ and other studies that an efficient environment that comes with more openness to trade is likely to attract more FDI inflows for faster growth. We want to add that FDI inflows and trade in productive sectors such as manufacturing will also boost growth. ${ }^{[16]}$ have concluded that unbalanced distribution of FDI inflows in favour of the mining sub-sector and trade in predominantly import-substituted goods in Ghana have failed to generate the necessary linkages to the wider economy for anticipated economic growth.

From the above background, it is imperative that the impact of FDI inflows and trade on economic growth need to be assessed for each country. The main objective for this study is to estimate the impact of FDI inflows and trade on economic growth in Ghana. The study will add valuable knowledge to the existing literature on Ghana.

Corresponding Author: Oteng-Abayie Eric Fosu, School of Business, Garden City University College, P.O. Box KS 12775, Kumasi, Ghana 
The study is relevant because the twin policy targets of FDI attraction and trade liberalisation have been integral preoccupation of various governments of Ghana since the IMF Structural Adjustment Programme of 1983. (See ${ }^{[17]}$ and $^{[18]}$ for more stylised facts on growth in Ghana). Again, the study uses a more recent data analysis technique (the bounds testing cointegration approach by ${ }^{[19]}$ which is more robust for the small sample nature of the times series used. We use annual time series data for the period 1970 to 2002 for which data is available.

\section{Analytical framework and data \\ Aggregate production function: Observing from} theory the possible growth promoting roles of both FDI and Trade, our data analysis is modelled in an aggregate production function (APF) framework. The standard APF model has been extensively used in econometric studies to estimate the impacts of FDI inflows and trade on growth in many developing countries. The APF assumes that, along with "conventional inputs" of labour and capital used in the neoclassical production function, "unconventional inputs" like FDI and trade may be included in the model to capture their contribution to economic growth. The APF model has been used by ${ }^{[6,7,20-23]}$.

Following ${ }^{[23]}$, the general APF model to be estimated is derived as:

$Y_{t}=A_{t} K_{t}^{\alpha} L_{t}^{\beta}$

where $Y_{t}$ denotes the aggregate production of the economy (real GDP per capita) at time $t$ and $A_{t}, K_{t}, L_{t}$ are the total factor productivity (TFP), the capital stock and the stock of labour, respectively. According to ${ }^{[24]}$, the impact of FDI on economic growth possibly operates through TFP $\left(A_{t}\right)$. Moreover, from the Bhagwati's hypothesis ${ }^{[14]}$, any gains from FDI on TFP will surely be dependent on the volume of trade of a particular host country. Since we want to investigate the impacts of FDI inflows $(F D I)$ and trade $(T R P)$ on economic growth through changes in TFP, we assume therefore that TFP is a function of FDI and TRP and other exogenous factors, $\left(C_{t}\right)$. Thus:

$A_{t}=f\left(F D I_{t}, T R P_{t}, C_{t}\right)=F D I_{t}^{\phi} T R P_{t}^{\delta} C_{t}$

Combining equations (2) with (1), we get:

$Y_{t}=C_{t} K_{t}^{\alpha} L_{t}^{\beta} F D I_{t}^{\phi} T R P_{t}^{\delta}$

We include a dummy variable $D$ representing economic liberalisation to take account of the trade regime switches in Ghana ( $D=1$ from 1969-1972 and 1983-2002; $D=0$ from 1973-1982). ${ }^{[18]}$ using a CobbDouglas production function has shown that economic liberalisation is significant and positive determinant of growth in Ghana for the period 1969 to 1996.

Equation (3) becomes:

$Y_{t}=C_{t} K_{t}^{\alpha} L_{t}^{\beta} F D I_{t}^{\phi} T R P_{t}^{\delta} D_{t}^{\psi}$ where $\alpha, \beta, \phi, \delta$, and $\psi$ are constant elasticity coefficients of output with respect to the $K_{t}, L_{t}, F D I_{t}$, $T R P_{t}$ and $D_{t}$. From equation (4), an explicit estimable function is specified, after taking the natural logs of both sides, as follows:

$$
\begin{aligned}
& \ln Y_{t}=c+\alpha \ln K_{t}+\beta \ln L_{t}+\phi \ln F D I_{t} \\
& +\delta \ln T R P_{t}+\rho \ln T R P_{t}+\psi D_{t}+\varepsilon_{t}
\end{aligned}
$$

where all coefficients and variables are as defined, $c$ is a constant parameter and $\varepsilon_{t}$ is the white noise error term. The sign of the constant elasticity coefficient $\alpha, \beta, \phi, \delta$, and $\psi$ are all expected to be positive. Equation (5) represents only the long-run equilibrium relationship and may form a cointegration set provided all the variables are integrated of order 1, i.e. I(1).

Data descriptions: From equation (5) $Y$ is defined as real GDP per capita; FDI is the value of real gross foreign direct investment flows; TRP is the sum of export and import values to GDP ratio; $L$ is measured as the volume of the total labour force; since a time-series on the capital stock is not directly available for Ghana, $K$ is proxied by the real value of gross fixed capital formation $(G F C F)$. This proxy for capital stock has been used in many previous studies ${ }^{[4,6,7]}$. $D$ is dummy variable for economic liberalisation in Ghana. The annual time series data used is sourced from the World Development Indicators 2004 edition published by the World Bank and covers the period from 1970 to 2002.

\section{Econometric methodology}

ARDL model specification: To empirically analyse the long-run relationships and dynamic interactions among the variables of interest, the model has been estimated by using the bounds testing (or autoregressive distributed lag (ARDL)) cointegration procedure, developed by ${ }^{[19]}$. The procedure is adopted for the following three reasons. Firstly, the bounds test procedure is simple. As opposed to other multivariate cointegration techniques such as Johansen and Juselius [25], it allows the cointegration relationship to be estimated by OLS once the lag order of the model is identified. Secondly, the bounds testing procedure does not require the pre-testing of the variables included in the model for unit roots unlike other techniques such as the Johansen approach. It is applicable irrespective of whether the regressors in the model are purely $\mathrm{I}(0)$, purely I(1) or mutually cointegrated. Thirdly, the test is relatively more efficient in small or finite sample data sizes as is the case in this study. The procedure will however crash in the presence of $\mathrm{I}(2)$ series.

Following ${ }^{[19]}$ as summarised in ${ }^{[26]}$, we apply the bounds test procedure by modelling the long-run equation (5) as a general vector autoregressive (VAR) model of order $p$, in $z_{t}$ : 
$z_{t}=c_{0}+\beta t+\sum_{i=1}^{p} \phi_{i} z_{t-i}+\varepsilon_{t}, t=1,2,3, \ldots, T$

with $c_{0}$ representing a $(k+1)$-vector of intercepts (drift) and $\beta$ denoting a $(k+1)$-vector of trend coefficients. ${ }^{[19]}$ further derived the following vector equilibrium correction model (VECM) corresponding to (6):

$\Delta z_{t}=c_{0}+\beta t+\Pi z_{t-1}+\sum_{i=1}^{p} \Gamma_{i} \Delta z_{t-i}+\varepsilon_{t}, t=1,2 \ldots, T$

where the $(k+1) \mathrm{x}(k+1)$-matrices $\Pi=I_{k+1}+\sum_{i=1}^{p} \Psi_{i}$ and $\Gamma_{i}=-\sum_{j=i+1}^{p} \Psi_{j}, i=1,2, \ldots, p-1 \quad$ contain the long-run multipliers and short-run dynamic coefficients of the VECM. $z_{t}$ is the vector of variables $y_{t}$ and $x_{t}$ respectively. $y_{t}$ is an $\mathrm{I}(1)$ dependent variable defined as $\ln Y_{t}$ and $x_{t}=\left[L_{t}, K_{t}, F D I_{t}, T R P_{t}\right]$ is a vector matrix of 'forcing' $\mathrm{I}(0)$ and $\mathrm{I}(1)$ regressors as already defined with a multivariate identically and independently distributed (i.i.d) zero mean error vector $\varepsilon_{t}=\left(\varepsilon_{1 t}, \varepsilon^{\prime}{ }_{2 t}\right)^{\prime}$, and a homoskedastic process. Further assuming that a unique long-run relationship exists among the variables, the conditional VECM (7) now becomes:

$$
\begin{aligned}
& \Delta y_{t}=c_{y 0}+\beta t+\delta_{y y} y_{t-1}+\delta_{x x} x_{t-1} \\
& +\sum_{i=1}^{p-1} \lambda_{i} \Delta y_{t-i}+\sum_{i=0}^{p-1} \xi_{i} \Delta x_{t-1}+\varepsilon_{y t}, t=1,2, \ldots, \mathrm{T}
\end{aligned}
$$

On the basis of equation (8), the conditional VECM of interest can be specified as:

$$
\begin{aligned}
& \Delta \ln Y_{t}=c_{0}+\delta_{1} \ln Y_{t-1}+\delta_{2} \ln L_{t-1}+\delta_{3} \ln K_{t-1} \\
& +\delta_{4} F D I_{t-1}+\delta_{5} \ln T R P_{t-1}+\sum_{i=1}^{p} \phi_{i} \Delta \ln Y_{t-i} \\
& +\sum_{j=1}^{q} \varpi_{j} \Delta \ln L_{t-j}+\sum_{l=1}^{q} \varphi_{l} \Delta \ln K_{t-l}+\sum_{m=1}^{q} \gamma_{m} \Delta F D I_{t-m} \\
& +\sum_{p=1}^{q} \eta_{p} \Delta \ln T R P_{t-p}+\psi D_{t}+\varepsilon_{t}
\end{aligned}
$$

where $\delta_{i}$ are the long run multipliers, $c_{0}$ is the drift and $\varepsilon_{t}$ are white noise errors.

Bounds testing procedure: The first step in the ARDL bounds testing approach is to estimate equation (9) by ordinary least squares (OLS) in order to test for the existence of a long-run relationship among the variables by conducting an F-test for the joint significance of the coefficients of the lagged levels of the variables, i.e., $H_{N}: \delta_{1}=\delta_{2}=\delta_{3}=\delta_{4}=\delta_{5}=0$ against the alternative $H_{A}: \delta_{1} \neq \delta_{2} \neq \delta_{3} \neq \delta_{4} \neq \delta_{5} \neq 0$. We denote the test which normalize on $Y$ by $F_{Y}(Y \mid L, K, F D I, T R D)$. Two asymptotic critical values bounds provide a test for cointegration when the independent variables are $\mathrm{I}(\mathrm{d})$ (where $0 \leq \mathrm{d} \leq 1$ ): a lower value assuming the regressors are $\mathrm{I}(0)$ and an upper value assuming purely $\mathrm{I}(1)$ regressors. If the F-statistic is above the upper critical value, the null hypothesis of no long-run relationship can be rejected irrespective of the orders of integration for the time series. Conversely, if the test statistic falls below the lower critical value the null hypothesis cannot be rejected. Finally, if the statistic falls between the lower and upper critical values, the result is inconclusive. The approximate critical values for the Ftest were obtained from ${ }^{[27]}$.

In the second step, once cointegration is established the conditional ARDL $\left(p_{1}, q_{1}, q_{2}, q_{3}, q_{4}\right)$ long-run model for $Y_{t}$ can be estimated as:

$$
\begin{aligned}
& \ln Y_{t}=c_{0}+\sum_{i=1}^{p} \delta_{1} \ln Y_{t-i}+\sum_{i=0}^{q_{1}} \delta_{2} \ln L_{t-i} \\
& +\sum_{i=0}^{q_{2}} \delta_{3} \ln K_{t-i}+\sum_{i=0}^{q_{3}} \delta_{4} F D I_{t-i}+\sum_{i=0}^{q_{4}} \delta_{6} \ln T R P_{t-p}+\psi D_{t}+\varepsilon_{t} \cdots
\end{aligned}
$$

Where, all variables are as previously defined. This involves selecting the orders of the ARDL $\left(p, q_{1}, q_{2}, q_{3}, q_{4}\right)$ model in the five variables using Akaike information criteria (AIC). In the third and final step, we obtain the short-run dynamic parameters by estimating an error correction model associated with the long-run estimates. This is specified as follows:

$\Delta \ln Y_{t}=\mu+\sum_{i=1}^{p} \phi_{i} \Delta \ln Y_{t-i}+\sum_{j=1}^{q} \varpi_{j} \Delta \ln L_{t-j}$

$+\sum_{l=1}^{q} \varphi_{l} \Delta \ln K_{t-l}+\sum_{m=1}^{q} \gamma_{m} \Delta F D I_{t-m}$

$+\sum_{p=1}^{q} \eta_{p} \Delta \ln T R P_{t-p}+\vartheta e c m_{t-1}+\varepsilon_{t}$

Here $\phi, \varpi, \varphi, \gamma$, and $\eta$ are the short-run dynamic coefficients of the model's convergence to equilibrium and $\vartheta$ is the speed of adjustment.

\section{RESULTS AND DISCUSSION}

Unit roots tests: Before we proceed with the ARDL bounds test, we test for the stationarity status of all variables to determine their order of integration. This is to ensure that the variables are not I(2) stationary so as to avoid spurious results. According to ${ }^{[28]}$ in the presence of $\mathrm{I}(2)$ variables the computed Fstatisticsprovided by ${ }^{[19]}$ are not valid because the bounds test is 
Am. J. Applied Sci., 3 (11): 2079-2085, 2006

Table 1: DF-GLS unit root tests on variables*

\begin{tabular}{|c|c|c|c|c|c|c|}
\hline \multicolumn{3}{|c|}{ Log Levels $\left(Z_{t}\right)$} & \multicolumn{4}{|c|}{$1^{\text {st }}$ differences $\left(\Delta Z_{t}\right)$} \\
\hline Variable & AIC lag & DFGLS stat & Variable & AIC lag & DFGLS stat & I (d) \\
\hline $\begin{array}{l}L Y \\
\end{array}$ & 3 & -0.8004 & $\Delta L Y$ & 1 & $-3.9846 * * *$ & I (1) \\
\hline$L L A B$ & 2 & -1.9844 & $\triangle L L A B$ & 1 & $-3.0387 * * *$ & I (1) \\
\hline$L C A P$ & 3 & -1.6221 & $\triangle L C A P$ & 1 & $-6.7996 * * *$ & I (1) \\
\hline$F D I$ & 4 & -0.6952 & $\Delta F D I$ & 1 & $-2.5203 * *$ & $\mathrm{I}(1)$ \\
\hline LTRD & 3 & -1.5328 & $\triangle L T R D$ & 3 & $-3.7499 * * *$ & I (1) \\
\hline
\end{tabular}

Notes: All variables are in logs except FDI due to negative numbers in the series. $\Delta$ is difference operator. The DF-GLS statistic are compared to the critical values from the simulated MacKinnon table in ERS (1996, Table 1, p.825). ***(**) denotes the rejection of the null at $1 \%(5 \%)$ significance level. *Results obtained from EViews 5.1.

Table 2: Results from bounds tests on equation (9)

\begin{tabular}{lllll}
\hline Dep. Var. & AIC Lags & F-statistic & Probability & Outcome \\
\hline$F_{Y}(Y \mid L, K, F D I, T R P)$ & 2 & 4.7836 & $0.009^{* * *}$ & Cointegration \\
$F_{L}(L \mid Y, K, F D I, T R P)$ & 2 & 1.5904 & 0.227 & No cointegration \\
$F_{K}(K \mid Y, L, F D I, T R P)$ & 2 & 1.3162 & 0.313 & No cointegration \\
$F_{F D I}(F D I \mid Y, L, K, T R P)$ & 2 & 7.4093 & $0.001^{* * *}$ & Cointegration \\
$F_{T R P}(T R P \mid Y, L, K, F D I)$ & 2 & 0.56039 & 0.729 & No cointegration
\end{tabular}

Notes: Asymptotic critical value bounds are obtained from Table F in appendix C, Case II: intercept and no trend for k=5 (Pesaran and Pesaran, 1997, p.478). Lower bound $\mathrm{I}(0)=3.516$ and Upper bound $\mathrm{I}(1)=4.781$ at $1 \%$ significance level.

based on the assumption that the variables are $\mathrm{I}(0)$ or I(1). Therefore, the implementation of unit root tests in the ARDL procedure might still be necessary in order to ensure that none of the variables is integrated of order 2 or beyond.

We applied a more efficient univariate DF-GLS test for autoregressive unit root recommended by ${ }^{[29]}$. The test is a simple modification of the conventional augmented Dickey-Fuller (ADF) $t$-test as it applies generalized least squares (GLS) detrending prior to running the ADF test regression. Compared with the ADF tests, the DF-GLS test has the best overall performance in terms of sample size and power. It "has substantially improved power when an unknown mean or trend is present" ${ }^{\text {"29] }}$. The test regression included both a constant and trend for the log-levels and a constant with no trend for the first differences of the variables. The DF-GLS unit root tests results for the variables reported in Table 1 indicate that all variables are $\mathrm{I}(1)$. ADF and ${ }^{[30]}$ Levin, Lin \& Chu pool (common unit root process) unit root tests not reported confirms the results. We rejected the null hypothesis of unit root process in all cases based on the Akaike Information Criteria (AIC) and serial correlations diagnostic test from the unit root test regression results.

Bounds tests for cointegration: In the first step of the ARDL analysis, we tested for the presence of long-run relationships in equation (6), using equation (9). We used a general-to-specific modelling approach guided by the short data span and AIC respectively to select a maximum lag order of 2 for the conditional ARDLVECM. Following the procedure $i^{[27]}$, we first estimated an OLS regression for the first differences part of equation (9) and then test for the joint significance of the parameters of the lagged level variables when added to the first regression. According to ${ }^{[27]}$, "this OLS regression in first differences are of no direct interest" to the bounds cointegration test. The Fstatistic tests the joint null hypothesis that the coefficients of the lagged level variables are zero (i.e. no long-run relationship exists between them). Table 2 reports the results of the calculated F-statistics when each variable is considered as a dependent variable (normalized) in the ARDL-OLS regressions.

The calculated F-statistics $F_{Y}(Y \mid L, K, F D I, T R P)=4.7836$ is higher than the upper bound critical value 4.781 at the $1 \%$ level. Also $F_{F D I}(F D I \mid Y, L, K, T R P)=7.4093$ is also higher than the upper-bound critical value 4.781 at the $1 \%$ level. Thus, the null hypotheses of no cointegration are rejected, implying long-run cointegration relationships amongst the variables when the regressions are normalized on both $Y_{t}$ and $F D I_{t}$ variables (Table 2). However, based on the growth theory, we used $Y_{t}$ as the dependent variable.

Once we established that a long-run cointegration relationship existed, equation (10) was estimated using the following ARDL $(1,0,0,0,0)$ specification. The results obtained by normalizing on real GDP per capita $\left(Y_{t}\right)$, in the long run are reported in Table 3.

The estimated coefficients of the long-run relationship show that capital investment proxied by real gross fixed capital formation has a very high significant impact on GDP per capita (economic growth). A $1 \%$ increase in capital investment leads to approximately $0.27 \%$ increase in GDP per capita, 
Table 3: Estimated long run coefficients using the ARDL approach

Equation (10): ARDL(1,0,0,0,0) selected based on AIC. Dependent variable is $\ln Y_{t}$.

\begin{tabular}{|c|c|c|c|c|}
\hline Regressor & Coefficient & Standard Error & T-Ratio & T-Probability \\
\hline$C$ & -0.086884 & 0.29740 & -.29215 & 0.773 \\
\hline $\ln L_{t}$ & -0.36356 & 0.15255 & $-2.3831 * *$ & 0.025 \\
\hline $\ln K_{t}$ & 0.27044 & 0.099651 & $2.7138 * * *$ & 0.012 \\
\hline$F D I_{t}$ & -0.90824 & 0.60582 & -1.4992 & 0.147 \\
\hline $\ln T R P_{t}$ & 0.13620 & 0.062824 & $2.1680 * *$ & 0.040 \\
\hline
\end{tabular}

***(**) denotes $1 \%(5 \%)$ significance level.

Table 4: Error correction representation for the selected ARDL model

ARDL $(1,0,0,0,0)$ selected based on AIC. Dependent variable is $\Delta \ln Y_{t}$.

\begin{tabular}{lllll}
\hline Regressor & Coefficient & Standard Error & T-Ratio & T-Probability \\
\hline $\mathrm{C}$ & -0.0269 & 0.0907 & -0.29698 & 0.769 \\
$\Delta \ln L_{t}$ & -0.1127 & 0.0686 & -1.6422 & 0.114 \\
$\Delta \ln K_{t}$ & 0.0838 & 0.0375 & $2.2339^{* *}$ & 0.035 \\
$\Delta F D I_{t}$ & -0.2816 & 0.1681 & -1.6749 & 0.107 \\
$\Delta \ln T R P_{t}$ & 0.0422 & 0.0180 & $2.3403^{* *}$ & 0.028 \\
$e c m(-1)$ & -0.3100 & 0.0964 & $-3.2163^{* * *}$ & 0.004
\end{tabular}

$e c m=\ln Y+0.364 * \ln L-0.27 * \ln K+0.908 * F D I-0.136 * \ln T R P+.08688 * C$

R-Squared $=0.530 \quad$ R-Bar-Squared $=0.432 \quad$ F-stat. $F(5,24)=5.418[0.002]$

SER $=0.0364 \quad$ RSS $=0.0318 \quad$ DW-statistic $=1.797$

Akaike Info. Criterion $=54.165$ Schwarz Bayesian Criterion $=49.962$

Table 5: ARDL-VECM model diagnostic tests

LM Test Statistics

\begin{tabular}{ll}
\hline Serial Correlation $\chi^{2}(1)=0.148[0.701]$ & Normality $\chi^{2}(2)=5.786[0.055]$
\end{tabular}

Functional Form $\chi^{2}(1)=0.247[0.620]$

Heteroscedasticity $\chi^{2}(1)=4.623[0.032]$
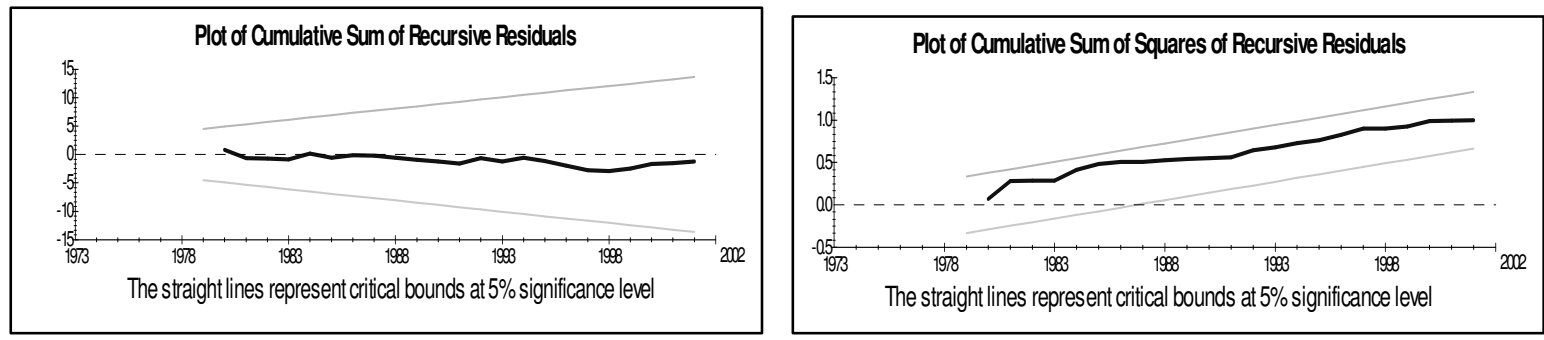

Fig. 1: Plot of Cusum and Cusumq for coefficients stability for ECM model

all things being equal. The labour force variable is negatively signed and very significant at the $2.5 \%$ level. This is indicative of the growing unemployment problem and the low productivity of labour in Ghana ${ }^{[18]}$. The economy of Ghana is based on land intensive agriculture, capital intensive mining and labour intensive petty trading all of which have limited employment and income generation benefits for the country.

Considering the impact of trade openness (sum of export and imports to GDP), it is significant at $4 \% \mathrm{t}-$ probability and has the expected positive impact on economic growth. A $1 \%$ increase in trade openness leads to a $0.06 \%$ in economic growth. Observe that the dummy variable for economic liberalization has been dropped because it was highly insignificant in all regressions but had a positive sign. To buttress the trade impacts on growth this means that to some extent economic liberalization has helped to open up the economy and raise economic growth. Interestingly, we found that the coefficient of foreign direct investment inflows (FDI) has a negative impact on growth and is even significant at $14 \%$ t-probability. This negative relationship between FDI and Growth in Ghana is consistent with a previous study by ${ }^{[16]}$.

The results of the short-run dynamic coefficients associated with the long-run relationships obtained from the ECM equation (11) are given in Table 4. The signs of the short-run dynamic impacts are maintained to the long-run. However, this time the labour force variable is only significant at $11 \%$ t-probability. FDI is also nearly significant at only $10 \%$. Capital investment 
and trade openness are both significant at the 5\% level and have relatively lower impacts on growth in the short-run and long-run compared to the other variables.

The equilibrium correction coefficient $(\mathrm{ecm})$, estimated $-0.31(0.0964)$ is highly significant, has the correct sign and imply a fairly high speed of adjustment to equilibrium after a shock. Approximately $31 \%$ of disequilibria from the previous year's shock converge back to the long-run equilibrium in the current year.

The regression for the underlying ARDL equation (9) fits very well at $\mathrm{R}^{2}=90 \%$ and also passes the diagnostic tests against serial correlation, functional form misspecification and non-normal errors (Table 5). It failed the heteroscedasticity test at 5\%. However according to ${ }^{[31]}$, "since the time series constituting the ARDL equation are potentially of mixed order of integration, i.e., $\mathrm{I}(0)$ and $\mathrm{I}(1)$, it is natural to detect heteroscedasticity". The cumulative sum (CUSUM) and cumulative sum of squares (CUSUMQ) plots (Fig. 1) from a recursive estimation of the model also indicate stability in the coefficients over the sample period.

\section{CONCLUSION}

This study has employed the bounds testing (ARDL) approach to cointegration to examine the long run and short run relationships between foreign direct investment, trade and economic growth using Ghana as the case study. The bounds test suggested that the variables of interest put in an aggregate production function framework are bound together in the long-run. The associated equilibrium correction was also significant confirming the existence of long-run relationships. The equilibrium correction is fairly fast and is restored by the first quarter of the year.

The results also indicate that labour, capital investment and trade are important in explaining economic growth in the long-run in Ghana. From the results, a policy suggestion for enhanced growth in Ghana will be to reform the labour sector in Ghana to ensure increased productivity. Therefore the current GPRS policy and Budget 2005 focus on human resource development is in the right direction. Trade openness effects on growth imply that trade liberalisation of the economy and export promotion since 1984 has been positive. However, the negative FDI effect which is consistent with past studies, confirms the mining sector FDI dominance which does not generate direct growth impacts on the wider economy. Attracting export-oriented FDI into the industrial and agricultural sectors of the economy of Ghana is of paramount importance if FDI is to have any positive growth impacts.

\section{REFERENCES}

1. Aryeetey, E., 2005. Globalization, Employment and Poverty in Ghana, WIDER Thinking Ahead: The Future of Development Economics, Marina Congress Center, Helsinki, 17-18 June 2005.
2. Frankel, J.A. and D. Romer, 1999. Does trade cause growth? Am. Econ. Rev., 89: 379-99.

3. Wacziarg, R., 2001. Measuring the dynamic gains from trade. World Bank Econ. Rev., 15: 393-429.

4. Balasubramanyam, V.N., M.A. Salisu and D. Sapsford, 1996. Foreign direct investment and growth in EP and IS countries. The Econ. J., 106: 92-105.

5. Borensztein, E., J.D. Gregorio and J.W. Lee, 1998. How does foreign direct investment affect economic growth? J. Intl. Econ., 45: 115-35.

6. Kohpaiboon, A., 2004. Foreign trade regime and FDI-growth nexus: A case study of Thailand. Working paper, Australian National University.

7. Mansouri, B., 2005. The interactive impact of FDI and trade openness on economic growth: Evidence from Morocco. Paper presented at the 12th Econ. Res. Forum (ERF) Conf., Cairo.

8. Karbasi, A., E. Mahamadi and S. Ghofrani, 2005. Impact of foreign direct investment on economic growth. Paper presented at the 12th Econ. Res. Forum Conf., $19^{\text {th }}-21^{\text {st }}$ Dec., Egypt.

9. Lipsey, R.E., 2000. Inward FDI and economic growth in developing countries. Transnational Corporations, 9: 61-95.

10. Pahlavani, M., E. Wilson and A.C. Worthington, 2005. Trade-GDP nexus in Iran: An application of autoregressive distributed lag (ARDL) model. Am. J. Appl. Sci., 2: 1158-1165.

11. De Mello, L.R., Jr., 1999. Foreign direct investment-led growth evidence from time series and panel data. Oxford Econ. Papers, 51: 133-151.

12. Xu, B., 2000. Multinational enterprises, technology diffusion and host country productivity growth. J. Develop. Econ., 62: 477-93.

13. Bhagwati, J.N., 1978. Anatomy and Consequences of Exchange Control Regimes, Vol. 1, Studies in International Economic Relations, 10 (New York: National Bureau of Economic Research).

14. Bhagwati, J.N., 1985. Investing Abroad; Esmee Fairbain Lecture, Lancaster University. Reprinted in V.N. Balasubramanyam (Ed.) J.N. Bhagwati, Writings on International Economics (1997, Delhi, Oxford University Press).

15. Asiedu, E., 2002. On the determinants of foreign direct investment to developing countries: Is Africa different? World Development, 30: 107-119.

16. Frimpong, J.M. and E.F. Oteng-Abayie, 2006. Bivariate causality analysis between FDI inflows and economic growth in Ghana. Proc. 3rd African Finance J. Conf., Research in Development Finance for Africa, 12th-13th Jul., Ghana.

17. Aryeetey, E. and J. Harrigan, 2000. Macroeconomic and Sectoral Developments since 1970 in Economic Reforms in Ghana, The Miracle and The Mirage. (Ed. E. Aryeetey, J. Harrigan and M. Nissanke, James Currey. Woeli Publishers, Oxford. 
18. Aryeetey, E. and A.K. Fosu, 2005. Economic Growth in Ghana: 1960-2000 AERC Growth Project Workshop, Cambridge.

19. Pesaran, M.H., Y. Shin and R.J. Smith, 2001. Bounds testing approaches to the analysis of level relationships. J. Appl. Economet., 16: 289-326.

20. Feder, G., 1983. On exports and economic growth. J. Develop. Econ., 12: 59-73.

21. Fosu, A.K., 1990. Export composition and the impact of exports on economic growth of developing economies. Econ. Lett., 34: 67-71.

22. Ukpolo, V., 1994. Export composition and growth of selected low-income African countries: Evidence from time-series data. Appl. Econ., 26: 445-449.

23. Herzer, D., D.F. Nowak-Lehmann and B. Siliverstovs, 2006. Export-led growth in Chile: Assessing the role of export composition in productivity growth. The Developing Econ., 44: 3.

24. Lipsey, R.E., 2001. Foreign direct investment and the operations of multinational firms: Concepts, history and data. NBER Working Paper $\mathrm{N}^{\circ} 8665$, Cambridge, MA. National Bureau of Economic Research.
25. Johansen, S. and K. Juselius, 1990. Maximum likelihood estimation and inference on cointegration-with application to the demand for money. Oxford Bull. Econ. Stat., 52: 169-210.

26. Choong, C.K., Y. Zulkornain and K.S. Venus, 2005. Export-led growth hypothesis in Malaysia: An investigation using bounds test. Sunway Acad. J., 2: 13-22.

27. Pesaran, M.H. and B. Pesaran, 1997. Working with Microfit 4.0: Interactive Econometric Analysis. Oxford, Oxford University Press.

28. Ouattara, B., 2004. Foreign Aid and Fiscal Policy in Senegal. Mimeo University of Manchester.

29. Elliot, G., T.J. Rothenberg and J.H. Stock, 1996. Efficient tests for an autoregressive unit root. Econometrica, 64: 813-36.

30. Levin, A., C.F. Lin and C. Chu, 2002. Unit root tests in panel data: Asymptotic and finite-sample properties. J. Economet., 108: 1-24.

31. Shrestha, M.B. and K. Chowdhury, 2005. ARDL modelling approach to testing the financial liberalisation hypothesis. Economics Working Paper Series 2005, University of Wollongong. 